\title{
KOMUNIKASI PEMBANGUNAN, PARTISIPASI MASYARAKAT DAN MEDIA ONLINE PADA PROGRAM BERBAGI AIR DI DESA PASAREAN KABUPATEN BOGOR
}

\author{
Irpan Ripa'i Sutowo ${ }^{(1)}$, Ratu Nadya Wahyuningratna ${ }^{(2)}$ \\ 1,2Program Studi IImu Komunikasi, Universitas Pembangunan NasionalVeteran Jakarta \\ JI. R.S Fatmawati No. 1, Jakarta Selatan 12450, Indonesia
}

Email: (1) irpan.sutowo@upnvj.ac.id, (2) ratunadyaw@upnvj.ac.id

\begin{abstract}
Abstrak
This study discusses the problem of access related to clean water and sanitation in rural settlements that do not have clean water and sanitation facilities to meet their daily needs in Pasarean Village, Pamijahan District, Bogor Regency. Citizens' efforts in dealing with problems are also described in this study. The background and problems of this research are the lack of access to clean water and sanitation in rural areas due to geographical factors, such as the position of being in the hills, into clean water, and the distance to access to get distant water. So the clean water sharing program in the form of well drilling was carried out to solve the problem, which was assisted by PKPU donors from humanitarian agencies. The purpose of this study is to determine the level of participatory development communication in water sharing programs. This research method is a qualitative descriptive method with data collection techniques, namely participatory observation. The results of this study indicate that development communication runs in a participatory manner, whereby the community participates actively in every process of building clean water facilities starting from planning to utilizing development programs. The level of community participatory development communication can be seen at the level of community participation, where community participation is at the level of acting together, which means that in achieving the goal of meeting the needs of clean water facilities the community does not merely participate in making decisions, but also engages and establish partnerships in the implementation of the program.
\end{abstract}

Keywords: clean water sharing program, development communication, community participatory

\section{PENDAHULUAN}

Permasalahan kesehatan lingkungan seringkali terjadi disebabkan oleh kurangnya sumber air bersih serta sanitasi yang layak. Sanitasi yang baik dan sumber air yang bersih akan mengurangi prevalensi penyakit, meningkatkan produktivitas, serta mengurangi polusi dari sumber air. Faktor lain yang juga menyebabkan permasalahan terhadap air bersih dan sanitasi layak di masyarakat adalah akses terhadap layanan air bersih dan sanitasi layak tersebut. Ketersediaan air bersih menjadi isu yang sangat penting karena hal tersebut mempunyai implikasi pada tingkat kualitas hidup masyarakat.

Salah satu wilayah yang memiliki permasalahan sanitasi terutama terkait dengan kelangkaan air bersih adalah Kabupaten Bogor. Air permukaan di wilayah Kabupaten Bogor kondisinya sudah sangat memprihatinkan karena pencemaran lingkungan. Untuk mendapatkan air bersih, diperlukan upaya penggalian atau pengeboran 
sumur dengan kedalaman yangcukup dalam berkisar 15-30 meter. Warga tidak sanggup untuk membangunsarana air bersih sendiri di rumahanya, karena sumur bor dengan kedalaman 15-30 meter tersebut membutuhkan dana yang tinggi. Oleh karena itu, program berbagi air bersih oleh PKPU Lembaga Kemanusiaan diharapkan dapat menjadi solusi bagi masyarakat. Program Berbagi air bersih merupakan program pembangunan sarana air bersih serta edukasi pola hidup bersih dan sehat (PHBS), menghadirkan solusi dalam meningkatkan kemampuan masyarakat untuk menjangkau sarana sanitasi demi terciptanya kesehatan masyarakat.

Hasil Assessment di Desa Pasarean, Kecamatan Pamijahan, Kabupaten Bogor menunjukan bahwa kondisi sarana air bersih yang dimiliki masyarakat masih minim, yaitu belum memiliki sarana air bersih untuk minum. Saat ini sumber air bersih yang digunakan untuk minum bersumber dari air Sungai Cigamea yang dialirkan ke rumah warga melalui program pipanisasi pemerintah. Kondisi air dari sungai cigamea ini sangat memperihatinkan karena kondisi air yang sudah tercemar oleh limbah rumah tangga seperti deterjen, sampah, pembuangan buang air besar (BAB), limbah perikanan, dan lainnya. Sumber air bersih yang digunakan untuk minum warga sebagian besar menggunakan air sungai tersebut yang ditampung pada ember lalu diendapkan selama beberapa hari, namun sebagian warga lainnya yang kondisi ekonominya baik, lebih memilih membeli air mineral(galon) atau air isi ulang. Kondisi air bersih lainnya yaitu sumur yang tidak layak konsumsi karena warnanya kuning dan berbau. Sumur-sumur warga telah ditutup karena alasan sudah diganti dengan air sungai dan air sumur yang tidak layak konsumsi.Adapun Program Berbagi Air Bersih ini memiliki tujuan yaitu (1) menciptakan derajat kesehatan masyarakat melalui penyediaan sarana sanitasi dan edukasi masyarakat; (2) mempermudah akses masyarakat untuk mendapatkan air bersih bagi kehidupan sehari-hari; dan (3) meningkatkan pengetahuan masyarakat terkait pola hidup bersih dan sehat (PHBS).

Program Berbagi Air Bersih ini merupakan salah satu program pembangunan di bidang kesehatan yang sangat diperlukan oleh masyarakat. Oleh sebab itu, komunikasi dalam pembangunan sangatlah penting dijalankan sebagai salah satu variabel dalam pencapaian tujuan progam pembangunan yang diharapkan. Komunikasi pembangunan dirasa penting untuk pengembangan partisipasi masyarakat dalam Program Berbagi Air Bersih di Desa Pasarean. Dalam hal ini, perlu diketahui bahwa tujuan komunikasi pembangunan tidak hanya untuk memasyarakatkan pembangunan dan penyampaian pesan-pesan pembangunan saja, tetapi yang lebih penting yaitu untuk menumbuhkan, menggerakan, dan memelihara partisipasi masyarakat dalam proses pembangunan. Oleh karena itu, dirasa penting dalam melakukan penelitian ini yang berjudul "Komunikasi Pembangunan, Partisipasi Masyarakat dan Media Online pada Program Berbagi Air di Desa Pasarean Kabupaten Bogor.”

\section{Komunikasi Pembangunan}

Nasution (2009) mengartikan komunikasi pembangunan secara luas dan sempit. Komunikasi pembangunan secara luas yaitu meliputi peran dan fungsi komunikasi sebagai suatu aktivitas pertukaran pesan secara timbal balik di antara semua pihak yang terlibat dalam usaha pembangunan, terutama anatara masyarakat dengan pemerintah dari proses perencanaan, pelaksanaan, hingga penilaian terhadap pembangunan sedangkan arti komunikasi pembangunan secara sempit yaitu segala upaya atau cara serta teknik penyampaian gagasan dan keterampilan-keterampilan pembangunan yang berasal dari pihak yang memprakarsai pembangunan dan ditujukan kepada masyarakat luas. Seiring berkembangnnya ilmu pengetahuan, paradigma komunikasi 
pembangunan bergeser dari komunikasi satu arah menjadi komunikasi dua arah atau sering disebut juga dengan istilah komunikasi pembanguan partisipatif. Altafin (1991) dalamMardikanto (2010) menyebut bahwa komunikasi partisipatif diidentifikasikan sebagai perangsang partisipasi, menstimulir berpikir kritis, dan mengutamakan proses, dibanding sekadar pengaruh khusus yang terkait dengan modernisasi yang linear. Pendapat yang sama dari Jahi (1988) menyampaikan bahwa masyarakat harus berperan dalam pembangunan baik dalam perencanaan maupun dalam pelaksanaanyang berarti bahwa pembangunan harus bersifat partisipatif.

\section{Komunikasi Pembangunan untuk Pengembangan Partisipasi Masyarakat}

Faktor-faktor penentu tumbuh dan berkembangnya partisipasi masyarakat dalam pembangunan yaitu melalui upaya kegiatan pemberdayaan masyarakat yang dalam prakteknya dilakukan melalui kegiatan komunikasi pembangunan. Komunikasi pembangunan adalah cara yang harus ditempuh untuk membangkitkan dan mengembangkan partisipasi masyarakat dalam proses pembangunan.Melalui komunikasi pembangunan diharapkan dapat: (1) menumbuhkan kesadaran masyarakat untuk berpartisipasi dalam pembangunan; (2) menginformasikan tentang adanya kesempatan bagi masyarakat untuk berpartisipasi dalam pembangunan; (3) menunjukkan dan meningkatkan kemampuan masyarakat untuk berpartisipasi; dan (4) menggerakkan kemampuan masyarakat untuk berpartisipasi (Mardikanto, 2009).

Slamet (1985) dalam Mardikanto (2010) mengemukakan adanya keberagaman partisipasi berdasarkan input yang disumbangkan dan keikutsertaannya dalam memanfaatkan hasil pembangunan, yang dapat dilihat pada Tabel 1.

Tabel 1 Ragam Bentuk Partisipasi Masyarakat

\begin{tabular}{|l|c|c|c|c|c|}
\hline \multirow{2}{*}{ Partisipasi yang ditunjukan } & \multicolumn{5}{c|}{ Ragam Partisipasi } \\
\cline { 2 - 7 } & $\mathbf{1}$ & $\mathbf{2}$ & $\mathbf{3}$ & $\mathbf{4}$ & $\mathbf{5}$ \\
\hline Memberi input & + & + & + & + & - \\
\hline Menerima imbalan atas input yang diberikan & + & - & + & - & - \\
\hline Menikmati manfaat hasil & + & + & - & - & $*$ \\
\hline
\end{tabular}

Penjelasan keragaman bentuk partisipasi masyarakat dalam suatu kegiatan masyarakat pada Tabel 1 yaitu sebagai berikut :

(1) Ikut memberikan input, menerima imbalan atas input yang diberikan, dan ikut memanfaatkan hasil pembangunannya. Partisipasi seperti ini dapat dijumpai pada petani yang ikut padat karya perbaikan saluran pengairan yang mengairi sawahnya.

(2) Berbeda dengan partisipasi bentuk pertama di atas, pada kasus ini, warga masyarakat yang terlibat dalam proses pembangunan tidak memperoleh imbalan atas korbanan yang diberikan tetapi juga ikut menikmati hasil pembangunan. Partisipasi bentuk ini dapat dijumpai pada petani yang bergotong royong memperbaiki saluran air pengairan yang mengairi sawahnya, atau anggota masyarakat yang bekerja sama membersihkan lingkungannya.

(3) Ikut memberikan input, menerima imbalan atas input yang diberikan tetapi tidak ikut memanfaatkan hasilnya. Partisipasi seperti ini, tidak dapat dilihat pada para pekerja bangunan yang turut dalam pembangunan hotel-hotel berbintang. Dalam kasus seperti ini, meskipun para pekerja tersebut turut 
berpartisipasi dalam pembuatan hotel, mereka tidak akan turut menikmati hasil pembangunannya, karena tidak akan mampu membayar sewa hotelnya.

(4) Ikut memberikan input, meskipun tidak menerima imbalan atas input yang diberikan, dan juga tidak ikut serta menikmati manfaat hasil pembangunan. Partisipasi seperti ini, bisa dilakukan oleh para penyumbang dana (donatur) atau sponsor-sponsor kegiatan sosial (pendirian panti asuhan, dan lainlain).

(5) Tidak Ikut membeikan input, sehingga tidak menerima imbalan, tetapi ada kemungkinan ikut menikmati hasil pembangunan.

\section{Tingkat Partisipasi Masyarakat}

Dilihat dari tingkatan atau tahapan partisipasi, Wilcox (1988) dalam Mardikanto (2009) mengemukakan adanya lima tingkatan, yaitu : (1) Memberi informasi (Informastion) yang berada pada tingkat partisipasi paling rendah; (2) Konsultasi (Consultation) yaitu menawarkan pendapat sebagai pendengar yang baik untuk memberikan umpan balik, tetapi tidak terlibat dalam implementasi ide dan gagasan tersebut; (3) Pengambilan keputusan bersama (Deciding together) yang berarti memberikan dukungan terhadap ide, gagasan, pilihan-pilihan, serta mengembangkan peluang yang diperlukan untuk pengambilan keputusan; (4) Bertindak bersama (Acting together), dalam arti tidak sekadar ikut dalam pengambilan keputusan, tetapi juga terlibat dan menjalin kemitraan dalam pelaksanaan kegiatannya; dan (5) Memberikan dukungan (Supporting independent community interest) dimana kelompok-kelompok lokal menawarkan pendanaan, nasehat, dukungan lain untuk pengembangan agenda kegiatan. Jenjang tingkat partisipasi masyarakat dalam suatu program pembangunan secara jelas dapat dilihat pada Gambar 1.

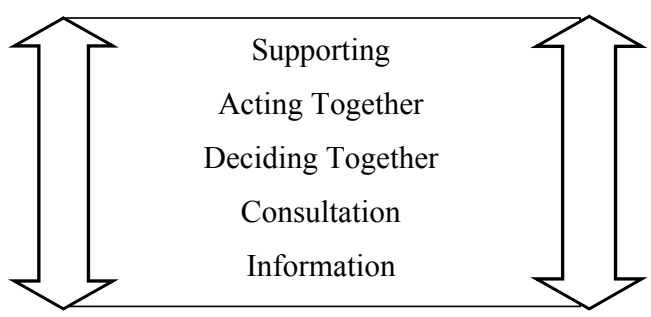

Gambar 1 Jenjang Tingkat Partisipasi

Gambar 1 menunjukan bahwa jenjang partisipasi masyarakat dalam suatu kegiatan memiliki perbedaan tingkatan. Tingkatan partisipasi masyarakat tertinggi adalah supporting (memberikan dukungan), dan yang terendah adalah information (memberikan informasi). Sehingga jika diperingkat atau diurutkan tingkat partisipasi masyarakat pada suatu kegiatan di masyarakat dari yang tertinggi hingga yang terendah adalahSupporting $>$ Acting Together $>$ Deciding Together $>$ Consultation $>$ Information.

\section{Media Online dalam Pembangunan}

Media massa meliputi media cetak, media elektronik, dan media online. Media cetak terbagi menjadi beberapa macam diantaranya seperti koran, majalah, buku, dan sebagainya, begitupula dengan media elektronik terbagi menjadi dua macam, diantaranya radio dan televisi, sedangkan media online meliputi media internet seperti website, dan lainnya (Yunus, 2010). 
Jika dilihat dari kemampuannya menarik perhatian manusia (masyarakat), ketiga jenis media massa tersebut sama-sama memiliki strategi dalam menarik perhatian khalayak. Mengenai menarik perhatian masyarakat, media sosial yang merupakan bagian dari media online bisa saja lebih aktif dalam mengalihkan perhatian masyarakat dari media massa dan hanya tertuju pada media sosial (Zarrella, 2010).

Pada dasarnya, media sosial merupakan perkembangan mutakhir dari teknologi web baru berbasis internet yang memudahkan semua orang untuk dapat berkomunikasi, berpartisipasi, saling berbagi, dan membentuk sebuah jaringan secara online sehingga dapat menyebarluaskan konten mereka sendiri. Post di blog, Twitter, dan YouTube dapat diproduksi dan dapat dilihat secara langsung oleh jutaan orang secara gratis.

Penggunaan media digital atau online bertujuan untuk mendapatkan informasi dan hiburan termasuk media sosial. Hal ini berkaitan langsung dengan perkembangan masyarakat informasi. Masyarakat Informasi yang disebut sebagai tahap setelah era industrialisasi atau yang lazim disebut masyarakat "post industry" istilah Daniel Bell atau gelombang ketiga menurut Alfin Toffler dinamakan sebagai masyarakat informasi (Agoeng Noegroho, 2010:25). Informasi merupakan data yang diolah melalui suatu sistem pengelola sehingga memiliki arti dan bernilai bagi seseorang. Dalam perkembangannya, informasi sering dikaitkan dengan teknologi yaitu komputer dan perangkatnya. Disadari atau tidak, dinamika informasi yang terjadi membawa perubahan bagi masyarakat. Masyarakat yang mendapat kesempatan dan akses informasi secara tepat dan cepat akan jauh lebih maju dibandingkan mereka yang kurang mendapat 'nasib' yang baik dalam hal perolehan informasi. Menurut Putu L. Pendit (2005), tujuan utama dari masyarakat informasi adalah mewujudkan masyarakat yang sadar tentang pentingnya informasi, ilmu pengetahuan dan teknologi terciptanya suatu layanan informasi yang terpadu, terkoordinasi dan terdokumentasi serta tersebarnya informasi ke masyarakat luas secara cepat, tepat dan bermanfaat. Masyarakat ditandai dengan adanya perilaku informasi yang merupakan keseluruhan perilaku penemuan informasi yang merupakan upaya dalam menemukan informasi dengan tujuan tertentu sebagai akibat adanya kebutuhan untuk memenuhi tujuan tertentu, perilaku mencari informasi yang ditujukan seseorang ketika berinteraksi dengan sistem informasi, dan perilaku informasi yaitu perilaku yang dilakukan seseorang ketika menggabungkan informasi yang ditemukannya dengan pengetahuan dasar yang sudah ia miliki sebelumnya (www.pustaka.ut.ac.id/dev25/ pdfprosiding2/fisip201004.pdf, diakses pada tanggal 25 Januari 2014). Dengan kata lain, bahwa masyarakat informasi menyadari betapa penting informasi yang mereka dapatkan untuk memenuhi kebutuhan yang mereka inginkan. Di era informasi ini, informasi menjadi bagian penting dalam kehidupan manusia.

Masyarakat yang mendapat kesempatan lebih dulu serta akses lebih luas dan tepat waktu akan dapat 'mengurus dan mengatur' dunia. Yasir Riady mengemukakan bahwa hal ini bisa terjadi karena adanya beberapa faktor penentu pembentukkan masyarakat informasi dalam karya tulisnya yang berjudul Mewujudkan Masyarakat Informasi Indonesia Dampak Sosial, Konsekuensi dan Kemungkinannya. Beberapa faktor tersebut adalah:

1. Kemajuan dalam pendidikan; Dengan kemampuan baca tulis dan pembelajaran seseorang mampu menguasai pengetahuan. Dijelaskan bahwa akses terhadap informasi pilihan yang memiliki nilai guna, berasal dari keaktifan dalam mencari informasi, biasanya melalui kebiasaan membaca. Salah satu budaya yang menyertai informasi adalah tingginya budaya baca. Budaya diawali dari sesuatu yang sering atau biasa dilakukan, sehingga akhirnya menjadi suatu kebiasaan. Keuntungan yang bisa 
diperoleh dari membaca antara lain ialah menguasai ilmu pengetahuan secara luas, meningkatkan kemampuan untuk meningkatkan taraf hidup, mengatasi masalah, serta mempertajam pandangan.

2. Perubahan karakteristik pola kerja; orang selalu mencari informasi dan pengetahuan agar bisa bekerja dengan cepat, efektif, dan efisien. Faktor kedua ini merupakan melengkapi dari faktor pertama dimana dengan tingginya budaya membaca yang dimiliki oleh masyarakat informasi maka akan memberikan pengaruh pada karakteristik seseorang. Masyarakat informasi selalu akan haus dengan informasi untuk memenuhi kebutuhan mereka. Hal ini juga merangsang perkembangan teknologi komunikasi yang lebih canggih dibandingkan sebelumnya. Hausnya terhadap informasi yang dibutuhkan inilah membuat masyarakat informasi menginginkan mencari informasi yang cepat, tepat dan akurat.

3. Perubahan dalam cara menyebarkan pengetahuan, mulai dari konvensional kepada penyebaran informasi yang menggunakan alat-alat canggih. Telah dijelaskan bahwa informasi adalah data yang diolah melalui sistem pengelola sehingga memiliki arti dan bernilai bagi seseorang. Proses penyebaran informasi yang dilakukan ketika teknologi belum canggih seperti saat ini dilakukan dengan cara yang sangat sederhana.

4. Perubahan dalam cara mencari pengetahuan, semakin besarnya rasa ingin tahu pada diri seseorang sehingga berupaya untuk mendapatkan informasi dengan spesifik. Melanjutkan dari faktor ketiga mengenai proses awal informasi dilakukan ketika sejarah peradaban manusia bermula.

5. Kemajuan dalam penciptaan alat-alat untuk menyebarkan dan mengakses pengetahuan baru. Informasi merupakan energi bahan yang berpola (patterned matterenergy) yang mempengaruhi probabilitas yang tersedia bagi seorang individu dalam pembuat keputusan.

\section{METODE}

Metode pengkajian digunakan dalam rangka mencapai tujuan penelitian maka penelitian menggunakan pendekatan penelitian kualitatif. Melalui pendekatan kualitatif, penelitian yang dilakukan akan lebih terperinci karena lebih memperhatikan pada kekayaan isu dan data yang dikumpulkan (Neuman, 2006). Sedangkan tipe penelitian ini menggunakan tipe deskriptif kualitatif dimana peneliti mendeskripsikan dan mengkonstruksikan hasil wawancara dan observasi terhadap subjek penelitian dengan menggunakan instrumen sistem kategori. Lebih lanjut Neuman (2006) menyatakan, bahwa penelitian kualitatif merupakan upaya untuk menggali informasi secara luas dan mendalam dari para informan atau subjek penelitian.

\section{Subjek Penelitian}

Lokasi penelitian ini dilakukan di Desa Pasarean Kecamatan Pamijahan Kabupaten Bogor karena beberapa wilayah di Desa Pasarean memiliki karakteristik geografis dan akses yang sulit dalam memperoleh air bersih. Hal ini diperkuat dengan adanya hasil assessment wilayah yang dilakukan oleh fasilitator program.

Populasi penelitian ini adalah para penerima manfaat Program Berbagi Air Bersih oleh PKPU Lembaga Kemanusiaan, khususnya di RW 01 Desa Pasarean sedangkan subjek penelitian dari populasi sasaran penelitian ini ditentukan berdasarkan teknik purposif karena tidak adanya kerangka sampling dari seluruh unsur-unsur yang terdapat dalam populasi tersebut. Dalam penelitian ini peneliti melakukan pengamatan kepada subyek 
penelitian yaitu penerima manfaat dari proses perencanaan, implemantasi, hingga evaluasi dan monitoring pada program tersebut.

\section{Teknik Pengumpulan Data}

Data dikumpulkan melalui observasi partisipan yang memungkinkan peneliti mengamati kehidupan individu atau kelompok dalam situasi riil dimana terdapat setting yang rill tanpa dikontrol atau diatur secara sistematis (Kriyantono, 2010).

\section{Teknik Analisis Data}

Analisis data dalam pendekatan kualitatif-konstruktivis didahului oleh upaya mengungkap trustworthiness dari para subjek penelitian, yaitu menguji kebenaran dan kejujuran subjek penelitian dalam mengungkapkan realitas. Trustworthiness ini diuji melalui pengujian: credibility subjek, dengan menguji jawaban-jawaban pertanyaan berkaitan dengan pengalaman dan pengetahuan mereka yang khas. Berikutnya adalah menguji authenticity, yaitu peneliti memberi kesempatan dan memfasilitasi pengungkapan konstruksi personal yang lebih detail. Selanjutnya peneliti melakukan triangulation analysis, yaitu menganalisis jawaban subjek penelitian dengan meneliti autentisitasnya berdasar data empiris yang ada. Peneliti menjadi fasilitator untuk menguji keabsahan setiap jawaban berdasarkan dokumen atau data lain, serta reasoning yang logis. Tahapan berikut adalah melakukan intersubjectivity analysis. Artinya semua pandangan, pendapat ataupun data dari suatu subjek penelitian, didialogkan dengan pendapat, pandangan, ataupun data dari subjek lainnya. Hasil dari wawancara dan observasi pada penelitian ini kemudian dianalisis dan diinterpretasi dengan menggunakan analisis kategorikategori (filling system) yang telah ditentukan alau dikenal dengan analisis domain, adapun kategori-kategori tingkat partisipasi masyarakat adalahdapat dilihat pada Tabel 2.

Tabel 2 Analisis Kategori Domain dan Taksonomik Tingkat Partisipasi Masyarakat

\begin{tabular}{|l|l|}
\hline \multicolumn{1}{|c|}{ Analisis Kategori Domain } & \multicolumn{1}{|c|}{ Analisis Kategori Taksonomik } \\
\hline Information & $\begin{array}{l}\text { Masyarakat hanya berpartisipasi dalam memberikan informasi, tanpa } \\
\text { terlibat pada tahap perencanaan maupun implementasi program berbagi } \\
\text { air bersih }\end{array}$ \\
\hline Consultation & $\begin{array}{l}\text { Masyarakat menawarkan pendapat sebagai pendengar yang baik untuk } \\
\text { memberikan umpan balik, tetapi tidak terlibat dalam implementasi ide } \\
\text { dan gagasan tersebut pada program berbagi air bersih }\end{array}$ \\
\hline Deciding together & $\begin{array}{l}\text { Masyarakat memberikan dukungan terhadap ide, gagasan, pilihan- } \\
\text { pilihan, serta mengembangkan peluang yang diperlukan untuk } \\
\text { pengambilan keputusan }\end{array}$ \\
\hline Acting together & $\begin{array}{l}\text { Masyarakat tidak sekadar ikut dalam pengambilan keputusan, tetapi juga } \\
\text { terlibat dan menjalin kemitraan dalam pelaksanaan kegiatannya }\end{array}$ \\
\hline Supporting independent \\
community interest & $\begin{array}{l}\text { Terdapat kelompok-kelompok masyarakat lokal yang menawarkan } \\
\text { pendanaan, nasihat, dan dukungan lain untuk pengembangan agenda } \\
\text { kegiatan }\end{array}$ \\
\hline
\end{tabular}




\section{HASIL DAN PEMBAHASAN}

\section{Program Berbagi Air Bersih}

Program Berbagi Air Bersih adalah sebuah program penyediaan sarana sanitasi oleh PKPU Lembaga Kemanusiaan yang bekerjasama dengan pihak lainnya. Program ini berupa pengadaan air bersih (Hygiene Sanitation) serta meningkatkan kesadaran masyarakat untuk berperilaku hidup bersih dan sehat. Kegiatan yang dilakukan pada program ini adalah pengadaan sarana air bersih, edukasi masyarakat dan pembentukan badan pengelola sanitasi. Dengan terselenggaranya kegiatan tersebut akan membantu mempercepat terciptanya derajat kesehatan masyarakat yang lebih baik. Adapun Program Berbagi Air Bersihmemiliki tujuan:

1. Menciptakan derajat kesehatan masyarakat melalui penyediaan sarana sanitasi dan edukasi masyarakat

2. Mempermudah akses masyarakat untuk mendapatkan air bersih bagi kehidupan sehari-hari

3. Meningkatkan pengetahuan masyarakat terkait pola hidup bersih dan sehat (PHBS)

Program Berbagi Air Bersih di Desa Pasarean telah dilakukan sebanyak dua kali. Pertama, Program Berbagi Air Bersih dilaksanakan pada bulan Mei-Juli 2015 berupa penyediaan sarana air bersih sumur bor dengan kedalaman 43 meter yang berlokasi di RT 02 RW 01 Desa Pasarean yang disponsori oleh penny appeal. Kedua, Program Berbagi Air Bersih dilaksanakan pada bulan November 2015-Februari 2016 yaitu penyediaan sarana air bersih berupa penambahan instalasi perpipaan yang mengairi RW 01 Desa Pasarean yang disponsori oleh PT Pembangunan Perumahan (PT PP).

Metode komunikasi pembangunan yang dilakukan dalam kegiatan ini adalah metode partisipatif; masyarakat diposisikan sebagai aktor utama dalam pemecahan masalah kehidupannya sendiri sedangkan PKPU memposisikan diri sebagai fasilitator terlaksananya program tersebut sehingga kegotongroyongan dan kemandirian merupakan kekuatan utama dalam memecahkan masalah terpenuhinya air bersih. Selain mengupayakan terbangunnya sarana air bersih, fasilitator program juga melakukan edukasi kepada masyarakat tentang pola hidup bersih dan sehat (PHBS) agar masyarakat memahami akan pentingnya kebersihan lingkungan untuk kesehatan masyarakat. Terakhir masyarakat membentuk badan pengelola sanitasi agar sarana yang sudah bangun terkelola dan terawat secara berkelanjutan. Secara umum skema yang dilakukan dalam mensuskseskan program ini dapat dilihat pada Gambar 2. 


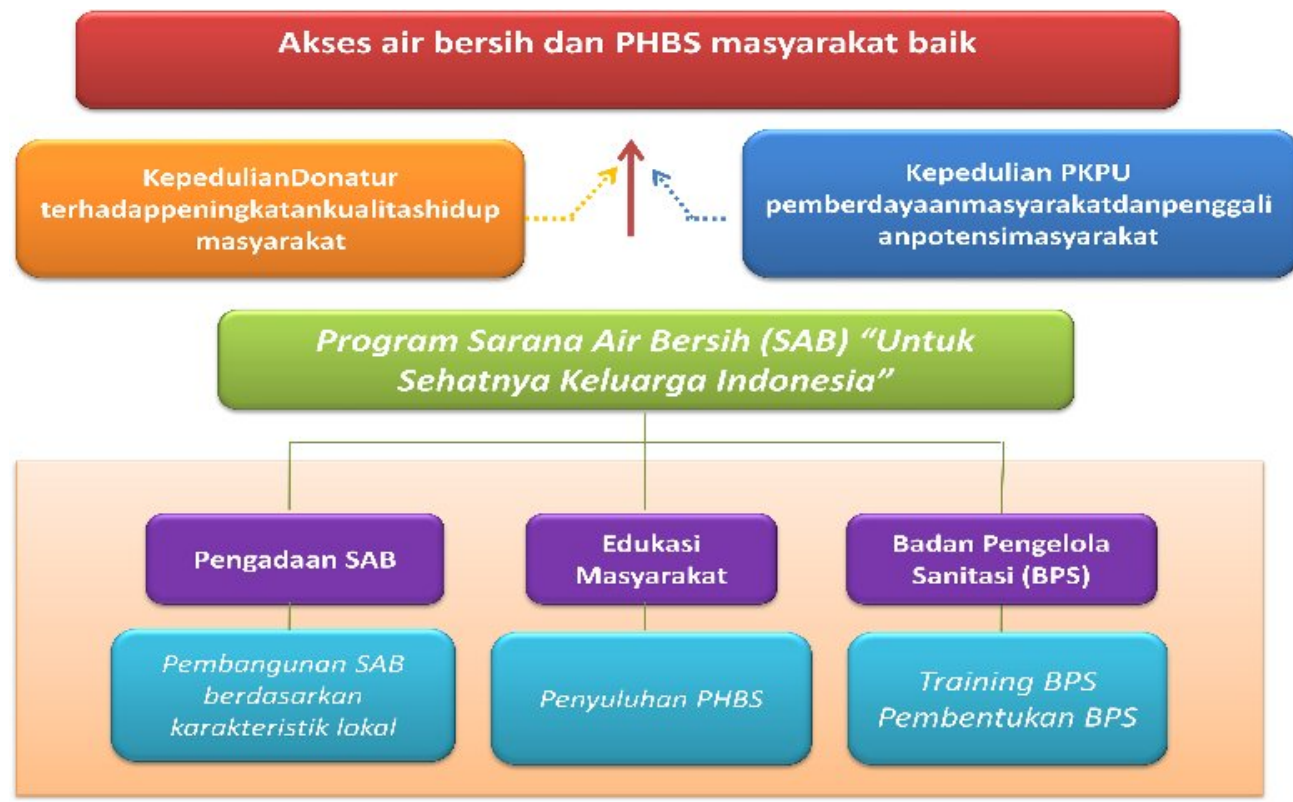

Gambar 2 Skema Program Berbagi Air di Desa Pasarean

Berdasarkan skema pada Gambar 2, program berbagi air di Desa Pasarean memiliki tujuan dan hasil harapan bersama, yaitu diharapkan dapat menciptakan derajat kesehatan masyarakat melalui penyediaan sarana sanitasi dan edukasi masyarakat, mempermudah akses masyarakat untuk mendapatkan air bersih bagi kehidupan sehari-hari, serta meningkatkan pengetahuan masyarakat terkait pola hidup bersih dan sehat (PHBS).

Pendekatan komunikasi yang dilakukan dengan pendekatan komunikasi partisifatif yaitu melalui media edukasi masyarakat berupa penyuluhan pola hidup bersih dan sehat (PHBS) dan pendampingan kader-kader kesehatan dengan membentuk badan pengelola sanitasi (BPS). Alhasil pendekatan komunikasi partisipatif dapat meningkatkan pengetahuan dan kesadaran masyarakat terkait perilaku hemat air, pengelolaan air, dan kebersihan lingkungan.

\section{Tahapan kegiatan Program Berbagi Air Bersih}

Program Berbagi Air Bersih di Desa Pasarean merupakan serangkaian kegiatan yang di setiap prosesnya melibatkan masyarakat yang didampingi oleh seorang fasilitator lapangan. Peneliti merupakan fasilitator yang mendampingi secara langsung setiap proses dari perencanaan hingga implementasi Program Berbagi Air Bersih di Desa Pasarean.Adapun tahapan-tahapan yang dijalankan fasilitator agar program berjalan dengan lancar yaitu melakukan assessment, rembug warga, pengadaan sarana air bersih, edukasi masyarakat,danpembentukan badan pengelola sanitasi.

\section{A. Assessment}

Pada tahap ini, dilakukan pengumpulan informasi terkait kondisi-kondisi geografis, demografi, sarana air bersih dan sanitasi, sosial ekonomi, dan pendidikan dengan metode survei, observasi, dan dokumentasi dari pihak terkait seperti pemerintah Desa Pasarean. Tujuan dari dilakukannya assessment ini yaitu untuk memperoleh data selengkap-lengkapnya terkait calon lokasi kegiatan dan agar pogram dijalankan tepat sasaran pada masyarakat yang membutuhkan. Adapun hasil assessment yang diperoleh yaitu sebagai berikut: 


\section{Kondisi Geografis}

Secara umum, Desa Pasarean berbatasan dengan Desa Situ Udik di sebelah utara, dengan Desa Pamijahan di sebelah selatan/barat, dengan Desa Gunung Menyan di sebelah utara/timur, dan dengan Desa Gunung Picung di sebelah timur/selatan. Desa Pasarean berada di wilayah Bogor Barat dan sangat jauh dari pusat kota Bogor. Akses menuju Desa Pasarean dapat di tempuh dengan kereta (Stasiun Bogor) lalu disambung dengan menggunakan angkutan umum kota dengan total jarak tempuh $+40 \mathrm{Km}$. Perjalanan menuju Desa Pasarean dapat ditempuh menggunakan Minibus, angkutan umum penghubung antar Desa (sampai dengan pukul 19.00 WIB), Kereta Api, dan Ojek.

\section{Kondisi Demografis}

Lokasi pembuatan sarana air bersih berupa penambahan pipanisasi dari sungai Cigamea ke RW 01 melintasi wilayah RW 05 Desa Pasarean. RW 01 Desa Pasarean memiliki 153 KK merupakan salah satu situs sejarah perjuangan kemerdekaan Indonesia dengan terbangunnya percontohan sistem komplek perumahan pertama di Indonesia. RW 01 memiliki 1 Masjid dan 1 mushola yang menjadi pusat kegiatan masyarakat. Masjid dan Mushola bernama Darul Hijrah yang dibangun berdasarkan inisiasi masyarakat dalam wadah lembaga Yayasan Darul Hijrah.

\section{Kondisi Sarana Air Bersih dan Sanitasi}

Kondisi sarana air bersih yang dimiliki masyarakat Kampung Pasarean masih minim, belum memiliki sarana air bersih untuk minum. Saat ini sumber air bersih yang digunakan untuk minum bersumber dari air sungai Cigamea yang dialirkan ke rumah warga melalui program pipanisasi pemerintah. Kondisi air dari sungai cigamea ini sungguh memperihatinkan karena kondisi air yang sudah tercemar oleh limbah rumah tangga seperti deterjen, sampah, limbah buang air besar (BAB), limbah perikanan dan lainnya. Sumber air bersih yang digunakan untuk minum warga sebagian besar menggunakan air tersebut yang ditampung pada ember lalu diendapkan selama beberapa hari, namun sebagian warga lainnya yang kondisi ekonominya baik, memilih membeli air mineral (gallon) atau isi ulang. Kondisi air lainnya yaitu sumur yang tidak layak konsumsi karena warnanya kuning (mengandung $\mathrm{Fe}$ ) dan berbau sehingga tidak layak konsumsi. Sumur-sumur warga telah ditutup selain tidak layak dikonsumsi juga karena alasan sudah diganti dengan air sungai.

\section{Kondisi Sosial Ekonomi}

Masyarakat RW 01 memiliki mata pencaharian sebagai buruh tani, peternak, dan pedagang. Jika melihat kondisi dan potensi alam yang ada, maka pengembangan usaha tani merupakan sebuah usaha yang prospektif. Potensi pengembangan usaha tani diantaranya yaitu pertanian sawah (padi dan palawija) dengan memiliki irigasi yang cukup baik, selain itu usaha tani perikanan cukup menjanjikan karena didukung dengan adanya sungai Cigamea yang memadai (produk unggulan ikan mas dengan running water system), dan usaha peternakan dengan pasokan sumber pakan hijauan yang melimpah cukup untuk memenuhi kebutuhan pakan ternak seperti domba, sapi, kerbau, dan lain sebagainya. 


\section{Kondisi pendidikan}

Masyarakat RW 01 rata-rata mengenyam pendidikan pada jenjang SD dan SLTP dan jarang yang melanjutkan pendidikan SLTA dan Perguruan Tinggi. Beberapa penyebab rendahnya tingkat pendidikan disana adalah jumlah sekolah yang minim di Desa Pasarean, yakni 3 TK, 5 SD/MI, 4 SLTP/MTS, dan hanya terdapat 1 sekolah untuk tingkat SLTA. Selain itu, biaya pendidikan yang tinggi juga dikeluhkan oleh para orang tua. Tingkat sadar pendidikan di masyarakat masih tergolong minim, sehingga orang tua lebih mengarahkan anakanaknya untuk tidak melanjutkan sekolah, dan mendorong anak perempuannya untuk menikah selepas lulus sekolah SLTP-SLTA, sedangkan anak laki-laki pergi merantau atau bekerja.

\section{B. Rembug Warga}

Setelah didapatkan hasil assessment maka diputuskan bahwa Desa Pasarean layak mendapatkan bantuan sarana air bersih untuk warga yang membutuhkan. Maka tahap selanjutnya adalah rembug warga atau melakukan pertemuan dan diskusi dengan tokoh-tokoh masyarakat terkait rencana kegiatan yang akan dilaksanakan di Desa Pasarean. Pada tahap ini tokoh-tokoh masyarakat diajak berdiskusi untuk menentukan rencana kegiatan yang akan dilaksanakan. Dari hasil rembug warga ini maka didapatkan beberapa kesepakatan yaitudiantaranya:

1. Pihak PKPU hanya menyediakan bantuan berupa penyediaan barang, tidak dalam uang tunai untuk membangun sarana air bersih masyarakat berupa penambahan pipa untuk disalurkan ke masyarakat.

2. Masyarakat berpartisipas menyediakan tenaga dan dapat meggerakan masyarakat untuk bergotong royong dalam kegiatan pembangunan sarana air bersih sampai dengan selesai.

3. Kegiatan akan didampingi oleh seorang fasilitator lapangan untuk melakukan pendampingan kepada masyarakat dan koordinasi antara pihak PKPU dan masyarakat.

\section{Pengadaan Sarana Air Bersih}

Tahap ini merupakan tahap implementasi pembangunan sarana air bersih. Persiapan implementasi ini yaitu berupa penentuan jumlah dan jenis material yang dibutuhkan untuk membangun sarana air bersih berupa penambahan pipanisasi. Selain itu juga masyarakat menjadwalkan kegiatan gotong royong dalam membangun sarana air bersih setiap minggunaya, sehingga program berjalan lancar dan tepat waktu. Dalam kegiatan gotong royong ini, partisipasi masyarakat cukup tinggi yaitu dapat dilihat dari kehadiran masyarakat dalam kegiatan gotong royong yang berjumlah 100-150 orang setiap minggunya.

\section{Edukasi Masyarakat dan Pembentukan Badan Pengelola Sanitasi (BPS)}

Sambil berjalannya kegiatan pengadaan sarana air bersih, setiap minggunya dilakukan kegiatan edukasi kepada masyarakat. Jadi, selain pembangunan fisik, PKPU juga melakukan pendampingan kepada masyarakat dengan melakukan edukasi dan pembentukan KERABAT (Kelompok Masyarakat Bina Sehat) yang kemudian diubah menjadi Kader Berdaya. Edukasi kepada masyarakat dilakukan dengan tujuan untuk meningkatkan kesadaran akan pentingnya air bersih untuk kesehatan dan menjaga air bersih dengan melakukan penghematan air bersih untuk masa mendatang.

Pembentukan Kader Berdaya dilakukan dengan pembentukan kelompok masyarakat. Kader Berdaya ini dibuat untuk mengelola sarana air bersih yang terbangun dan mampu menjadi motor penggerak di masyarakat 
untuk mengedukasi kembali masyarakat di RW 01 dan sekitarnya untuk berpartisipasi dalam menciptakan lingkungan yang sehat dan layak. Salah satu produk dari Kader Berdaya adalah pengesahan AD/ART untuk pengelolaan sarana air bersih secara merata dengan menggunakan sistem water meter. AD/ART dibuat untuk membuat peraturan cara penggunaan air, biaya, dan punishment. sedangkan pemasangan water meter diharapkan dapat menjadi solusi dalam pemerataan air bersih di Kampung Pasarean dan mengurangi kebocoran air.

\section{Tingkat Partisipasi Masyarakat dalam Program Berbagi Air Bersih di Desa Pasarean}

Sebelum menganalisis dan mengetahui tingkat partisipasi masyarakat, terlebih dahulu peneliti akan memaparkan keragaman bentuk partisipasi masyarakat pada Program Berbagi Air di Desa Pasarean. Berdasarkan pengamatan peneliti didapat bahwa ragam bentuk partisipasi masyarakat pada Program Berbagi Air yaitu masyarakat masuk dalam bentuk partisipasi kedua yaitu masyarakat desa pasarean khususnya RW 01 terlibat dalam proses pembangunan sarana air baik pada tahap perencanaan, implementasi, hingga monitoring-evaluasi. Warga RW 01 Desa Pasarean pun tidak memperoleh imbalan atas korbanan input yang diberikan, tetapi semua warga RW 01 dapat menikmatihasil pembangunan sarana air bersih diupayakan bersama-sama baik dari pihak intenal masyarakat RW 01 maupun pihak eksternal seperti PKPU dan PT Pembangunan Perumahan sebagai supporter. Keragaman bentuk partisipasi dapat tergambarkan oleh beberapa dokumentasi kegiatan masyarakat pada program berbagi air bersih dalam Gambar 3 dan Gambar 4.

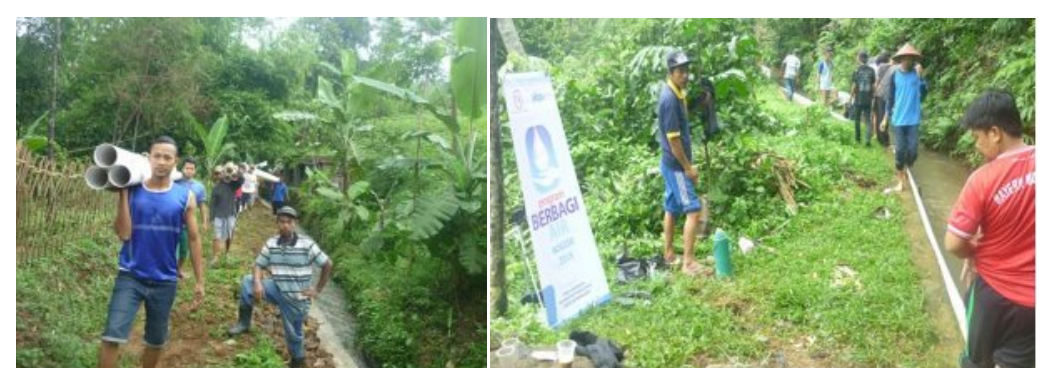

Gambar 3 Gotong Royong Instalasi Pipa

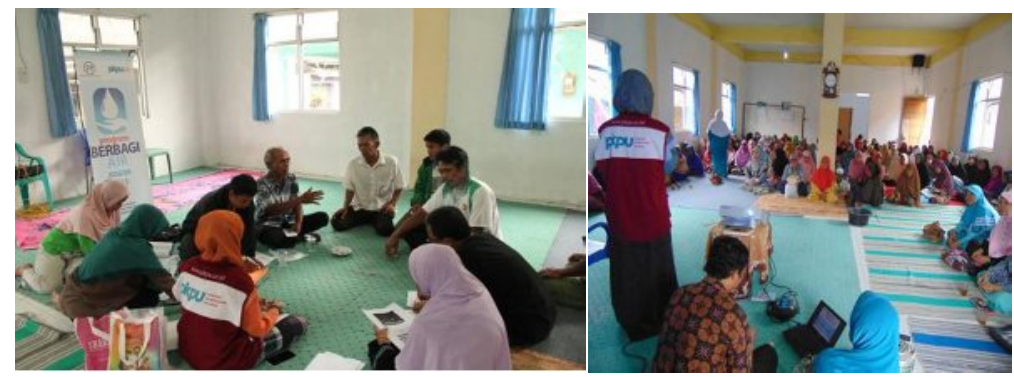

Gambar 4 Rembug dan Edukasi Warga

Selain gotong royong instalasi pipa yang terlihat pada Gambar 3, partisipasi aktif masyarakat dalam Program Berbagi Air Bersih ini juga terlihat pada kegiatan lainnya seperti keikutsertaan pada kegiatan assessment, rembug warga, implementasi, edukasi, dan lainnya yang secara rinci dapat dilihat pada Tabel 3. Tabel 3 menunjukan peran aktif masyarakat dalam proses pembangunan sumberdaya fisik maupun sumberdaya manusia demi tercapainya tujuan bersama yaitu meningkatkan kualitas hidup bersama.Dapat dilihat juga pada Tabel 3 proses perjalanan waktu yang sudah ditentukan dalam pencapaian program serta jumlah partisipasi masyarakat di setiap kegiatan yang telah direnacakan bersama. 
Tabel 3 Waktu, Kegiatan dan Jumlah Partisipan pada Program Berbagi Air di Desa Pasarean

\begin{tabular}{|c|c|c|}
\hline Waktu & Kegiatan & Jumlah Partisipan (orang) \\
\hline \multirow{4}{*}{$\begin{array}{l}\text { September- } \\
\text { Oktober } 2015\end{array}$} & Penentuan lokasi / Koordinasi stakeholder : & - \\
\hline & Desa Pangkalan & 5 \\
\hline & Desa Bojongmangu & 5 \\
\hline & Desa Pasarean & 4 \\
\hline \multirow{5}{*}{ November 2015} & Pemicuan & 36 \\
\hline & Rembug Warga dan Koordinasi Stakeholder & 7 \\
\hline & Pembentukan dan Pelatihan KERABAT & 7 \\
\hline & Kunjungan ke PDAM Tirta Kahuripan Kab. Bogor & 2 \\
\hline & $\begin{array}{l}\text { Kunjungan ke PDAM Tirta Kahuripan Kab. Bogor } \\
\text { bersama Kader Berdaya }\end{array}$ & 2 \\
\hline \multirow{5}{*}{ Desember 2015} & Pendampingan Kader Berdaya (membuat rencana kerja) & 5 \\
\hline & $\begin{array}{l}\text { Pendampingan Kader Berdaya oleh PDAM Pusat Kab } \\
\text { Bogor (survei dan membuat rancangan instalasi } \\
\text { pipanisasi) }\end{array}$ & 20 \\
\hline & Diskusi dan belanja alat-alat instalasi perpipaan & 6 \\
\hline & $\begin{array}{l}\text { Pembangunan instalasi } \\
\text { penampungan/penyaringan }\end{array}$ & 140 \\
\hline & Edukasi ibu-ibu tentang hemat air & 40 \\
\hline \multirow{3}{*}{ Januari 2016} & $\begin{array}{l}\text { koordinasi dengan stakeholder dan pendampingan oleh } \\
\text { expert (pemasangan water meter dan } \mathrm{AD} / \mathrm{ART} \text { ) }\end{array}$ & 9 \\
\hline & Peresmian & 35 \\
\hline & Koordinasi dengan Yayasan Darul Hijrah & 4 \\
\hline Februari 2016 & $\begin{array}{l}\text { Penetapan SK kepengurusan air bersih dan penetapan } \\
\text { AD/ART bersama Yayasan Darul Hijrah }\end{array}$ & 10 \\
\hline \multicolumn{2}{|r|}{ Total Partisipan Kegiatan } & 309 \\
\hline
\end{tabular}

Sumber: Laporan Program Berbagi Air PKPU Tahun 2016

Tabel 3 menggambarkan partispasi aktif masyarakat pada Program Berbagi Air yang bisa dibilang tinggi dan kooperatif sehingga pencapaian atau keberhasilan program ini dapat dikatakan sukses karena semua yang telah direncanakan berjalan sesuai apa yang diharapkan. Pengukuran keberhasilan program ini dapat dilihat pada Tabel 4 dengan membandingkan antara tujuan (objektive) dari program dengan indikator keberhasilan program tersebut, sehingga didapat persentase capaian Program Berbagi Air Bersih pada setiap tujuan yang dinginkan. Berdasarkan Logical Framework Analysis(LFA) yang telah dibuat untuk mengukur keberhasilan program, didapatkan hasil sebagai berikut pada Tabel 4. 
Tabel 4 Capaian Program Berbagi Air Bersih di Desa Pasarean

\begin{tabular}{|c|c|c|c|}
\hline \multicolumn{2}{|c|}{$\begin{array}{c}\text { Objective(spesifikasi } \\
\text { "produk" dari deliverable) }\end{array}$} & Indicators of Success (indikator keberhasilan*kuantitatif) & $\begin{array}{c}\text { Capaian } \\
(\%)\end{array}$ \\
\hline \multirow[t]{2}{*}{1} & \multirow[t]{2}{*}{$\begin{array}{l}\text { Akses air bersih tersedia } \\
\text { secara berkelanjutan }\end{array}$} & $\begin{array}{l}\text { Terbangunnya sarana air bersih yang sesuai dengan potensi } \\
\text { lokal dan sanggup melayani kebutuhan air untuk } 120 \mathrm{KK}\end{array}$ & 100,00 \\
\hline & & Masyarakat mengetahui kualitas air yang digunakan & 100,00 \\
\hline \multirow[t]{5}{*}{2} & \multirow[t]{5}{*}{$\begin{array}{l}\text { Kerabat PKPU } \\
\text { terbentuk dan mampu } \\
\text { menjalankan fungsinya }\end{array}$} & $\begin{array}{l}\text { Terbentuknya kelompok maksimal } 5 \text { orang sebagai pengelola } \\
\text { sarana air bersih dengan kewenangan yang dilegitimasi di } \\
\text { tingkat RW dan Kelurahan (harus mandiri) }\end{array}$ & 100,00 \\
\hline & & $\begin{array}{l}\text { Terlaksananya TOT Kerabat sebanyak } 7 \mathrm{X} \text { per periode } \\
\text { program dan mendapatkan nilai post-test minimal } 7 \text { dari skala } \\
10\end{array}$ & 42,86 \\
\hline & & $\begin{array}{l}\text { Terlaksananya edukasi masyarakat sebanyak } 3 \mathrm{x} \text { per periode } \\
\text { program dan adanya perubahan perilaku tentang pengelolaan } \\
\text { air minum meningkat positif } 70 \%\end{array}$ & 100,00 \\
\hline & & $\begin{array}{l}\text { Kerabat mampu menyusun dan mengawal pengesahan } \\
\text { peraturan mengenai mekanisme pengelolaan sarana air bersih } \\
\text { yang dilegitimasi di tingkat RW dan Kelurahan }\end{array}$ & 100,00 \\
\hline & & $\begin{array}{l}\text { Kerabat mampu mengelola sarana air bersih yang sudah } \\
\text { terbangun }\end{array}$ & 100,00 \\
\hline & & Rataan Capaian & 91,83 \\
\hline
\end{tabular}

Sumber: Laporan Program Berbagi Air PKPU Tahun 2016

Tingkat partisipasi masyarakat RW 01 Desa Pasarean dapat diukur dengan melihat sejauh mana atau pada tahapan partisipatori mana masyarakat berada.Mengacu pada tahap partisipatori yang dikemukanan oleh Wilcox (1988) dalam Mardikanto (2010) tahap partisipatori meliputi jenjang tingakatan terendah hingga tertinggi yaitu Information, Consultation,Deciding together, Acting together, dan Supporting independent community interest. Berdasarkan hasil pengumpulan data dan observasi peneliti terhadap proses kegiatan Program Berbagi Air di Desa Pasarean, maka didapat hasil bahwa setiap jenjang tingkat partispatori masyarakat pengaruhi beberapa faktor seperti kondisi sosial ekonomi, gender, dan waktu atau kesempatan. Sebagai contoh masyarakat di RW 01 sebagian besar tidak bisa menghadiri seluruh kegiatan dalam Program Berbagi Air karena ada yang sedang bekerja di sawah untuk memenuhi kebutuhan hidupnya, ada mengurus rumah tangga, dan kegiatan lainnya. Namun hal tersebut bukan berarti masyarakat tidak bisa berkontribusi dalam kegiatan tersebut. Jika mengacu pada jumlah partisipan setiap kegiatan yang dilakukan pada Tabel 3, maka jumlah partisipan setiap kegiatan tidak merepresentasikan jumlah pendududuk RW 01 yang berjumlah153 KK. Namun data menunjukan bahwa partisipasi masyarakat terlihat pada aktivitas gotong royong mingguan dan dukungan warga seluruh RW 01 dalam melakasnak dan mensuksekan Program Berbagi Air ini. Hal ini dapat dilihat dari capaian indikator keberhasilan dalam setiap kegiatan yang didukung penuh oleh warga RW 01 Desa Pasarean.

Serangakaian proses kegiatan yang dilaksanakan masyarakat beserta PKPU dan Donatur secara keseluruhan telah berhasil mengembangkan partisipasi masyarakat pada jenjang Acting Together, yang artinya masyarakat 
RW 01 Desa Pasarean tidak sekadar ikut dalam pengambilan keputusan, tetapi juga terlibat dan menjalin kemitraan dalam pelaksanaan kegiatannya. Dalam hal ini, kemitraan yang dibangun pada Program Berbagi Air Bersih yaitu dengan pihak PKPU, PT PP, Pemerintah Desa, dan PDAM Pusat Kab Bogor. Selain itu, tingkat partisipasi masyarakat berpotensi untuk ditingkatkan dengan mengoptimalkan fungsi-fungsi kelompokkelompok masyarakat lokal seperti Yayasan Darul Hijrah, Kelompok Pemuda, Kelompok Majlis Pengajian dan kelompok lainnya dalam memperoleh dan menawarkan pendanaan, nasehat, dukungan lain untuk pengembangan agenda kegiatan selanjutnya.

\section{Media Online dalam Program Berbagi Air Bersih}

Media online yang digunakan untuk menyampaikan pesan pembangunan yaitu melalui channel YouTube yang dimiliki oleh PKPU. Pada channel YouTube ini hanya video dokumenter program berbagi air PKPU-PT PP yang ditayangkan. Tujuan dari penayangan video dokumenter proses pembangunan sarana air bersih ini, selain untuk media promosi pihak terkait, yaitu untuk menyampaikan pesan pembangunan di bidang kesehatan (sanitasi) yang terjadidi Desa Pasarean Kab. Bogor, agar masyarakat memperoleh informasi terkait pemecahan masalah sosial ini melalui program berbagi air yang dilaksankan oleh PKPU-PT. PP. Video dokumenter ini ditayangkan pada tanggal 23 Febuari 2016 dengan nama akun Mitra Program PKPUdan dapat diakses pada link youtube: https://www.youtube.com/watch?v=mr3zGrgP67c. Video dokumenter yang memiliki durasi 8 menit 11 detik ini telah ditonton 32 kali, namun hanya sedikit mendapat like (2) dan subscribe (6). Berikut Gambar Screen shot dari channel youtube akun Mitra Program PKPU Program Berbagi Air (Pipanisasi) PKPU - PT. PP dapat dilihat pada Gambar 5.

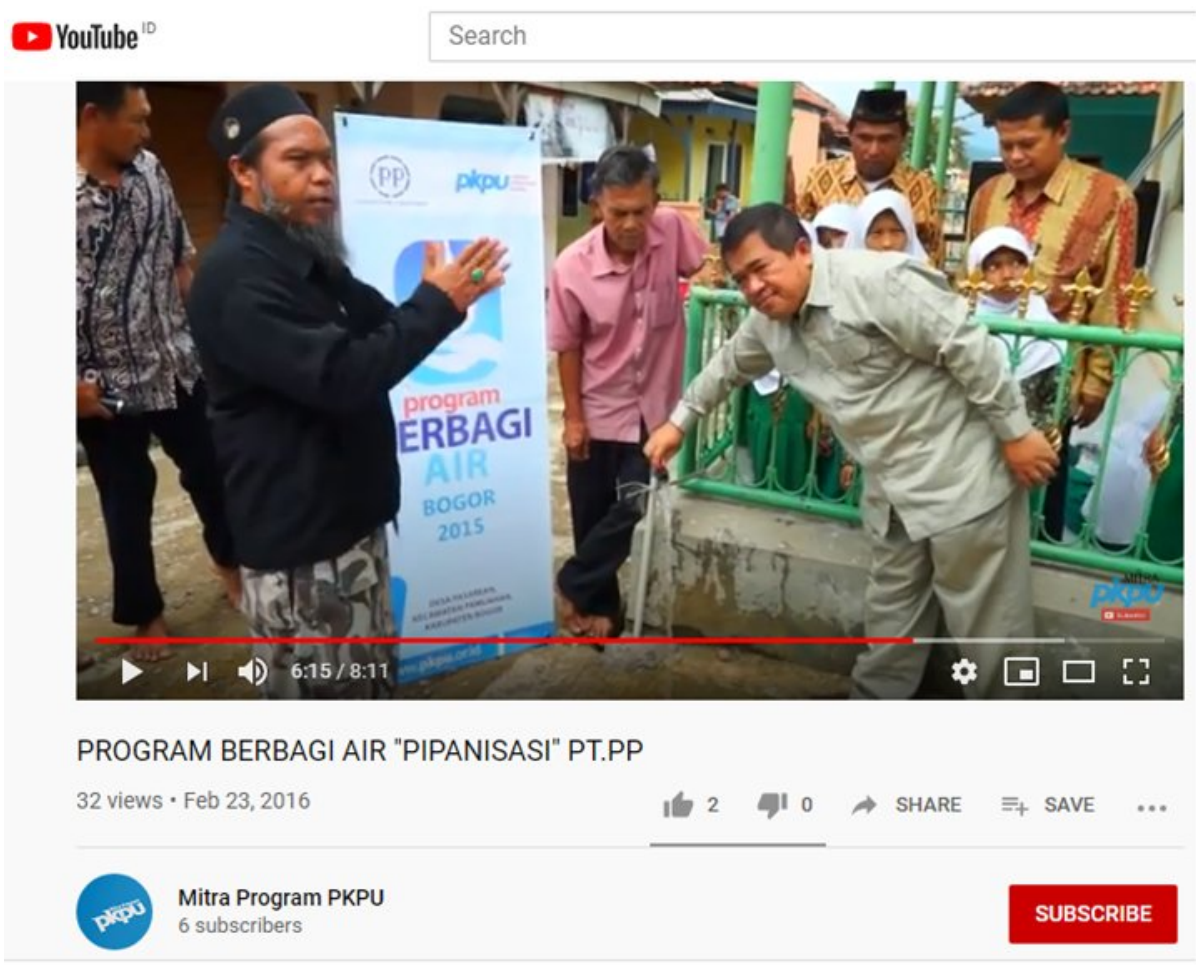

\section{Gambar 5 Screen Shot Program Berbagi Air (Pipanisasi) PKPU - PT. PP}

Di dalam video dokumenter tersebut, diceritakan bagaimana proses program berbagi air bersih ini, yang dimulai dari kegiatan assessment wilayah hingga peresmian dan pemanfaatan sarana air bersih Desa Pasarean, 
Kab. Bogor. YouTube adalah sumber daya yang sangat baik untuk video online. Situs ini sangat berbeda dalam penawaran mereka untuk pengguna upload. Panjang video, penonton, dan alat-alat yang tersedia bervariasi. Streaming resources video untuk pengajaran, learning, dan penelitian, akan juga mencakup beberapa sangat baik akses terbuka, seluruh negara bagian, dan inisiatif video online kelembagaan, serta interdisipliner situs dengan koleksi video online besar dalam berbagai kategori dan topik (DeCesare, 2014). Faiqah et al. (2016) menjabarkan manfaat-manfaat youtube diantaranya adalah 1) memberikan layanan gratis; 2) men-download (unduh) beberapa video tertentu; 3) mengakses dan berbagi informasi seputar hal-hal teknis; 4) mengakses video streaming; 5) mengenalkan dan memasarkan produk; 6) mengakses video informatif; 7) mendukung industri hiburan; 8) menguatkan branding lembaga/insititusi; 9) mengetahui respon dan komentar khalayak; dan 10) memfasilitasi pengguna menguasai skill dasar membuat video.

Channel YouTube Mitra Program PKPU dirasa belum banyak diminati oleh khalayak karena banyak faktor, di antaranya jenis kontennya yang tidak begitu banyak diminati khalayak seperti konten pendidikan maupun yang bersifat pembelajaran. Mangole et al. (2017) menyampaikan bahwa Pemahaman masyarakat tentang penggunaan aplikasi youtube sudah mulai dimengerti dengan baik, karena kebanyakan aplikasi youtube tersebut sudah ada pada smartphone masyarakat setempat, Nnamun belum terlalu optimal dimanfaatkan untuk menambah pengetahuan masyarakat, dimana seringkali atau kebanyakan masyarakat menggunakan aplikasi youtube hanya untuk memenuhi kebutuhan akan hiburan film dan musik yang bisa dilihat pada youtube tersebut. Oleh karena itu untuk meningkatkan minat khalayak perlu adanya inovasi dan peningkatan konten-konten YouTube Mitra Program PKPU yang sesuai dengan keinginan khalayak namun tidak mengurangi makna pesan pembangunan yang ingin disampaikan kepada khalayak.

Kondisi masyarakat era digital memiliki karakteristik yang berbeda daripada keadaan masyarakat di era sebelumnya. Hal tersebut memberikan implikasi secara langsung terhadap proses pembangunan nasional. Program Berbagi Air ini diharapkan dapat memberikan inspirasi dan pengetahuan kepada masyarakat luas terkait pembangunan kesejahteraan masyarakat melalui video dokumenter yang ditayangkan pada media digital YouTube. Menurut Suri (2019) Pembangunan nasional dilihat dari SDM, tempat atau lingkungan masyarakat, dan pendidikan harus dapat memprediksi sekaligus mengendalikan penggunaan media komunikasi yang berlebihan dan tidak beretika dengan baik. Hal tersebut dapat terlaksana dengan baik apabila adanya suatu kerjasama antara masyarakat dengan pemerintah daerah setempat yaitu melalui penyuluhan terhadap masyarakat mengenai etika berkomunikasi dengan media komunikasi yang baik dan menyampaikan aspirasi serta persoalan yang terjadi di dalam masyarakat dengan cepat, benar dan dapat dipertanggung jawabkan kebenarannya. Serta beberapa hal yang dapat direkomendasikan kepada para pengambil kebijakan dan praktisi pendidikan. Diperkuat dengan pendapat Putri (2013) yang menyampaikan bahwa pembentukkan struktur penyampaian pesan yang baik akan membentuk persepsi yang baik pula serta memberikan efek besar bagi pencitraan pembangunan atau program pembangunan yang sampaiakan untuk kedepannya

\section{KESIMPULAN}

Berdasarkan hasil penelitian dan pembahasan ini, diperoleh kesimpulan bahwa masyarakat RW 01 Desa Pasarean berperan aktif dalam setiap proses perencanaan, implementasi, hingga monitoring-evaluasi Program

Berbagi Air yang difasilitasi oleh PKPU Lembaga Kemanusiaan bekerjasama dengan PT Pembangunan 
Perumahan. Hal ini mengindikasikan bahwa tingkat partisipasi masyarakat dapat dikatakan tinggi, yang masuk pada jenjang Acting Together.

Pendekatan komunikasi pembangunan partisipatif yang digunakan dalam program ini dapat dikatakan sudah tepat dan efektif dalam menumbuhkan dan mengembangkan partisipasi masyarakat dalam tujuan peningkatan kualitas hidup atau derajat kesehatan masyarakat yang diharapkan bersama sehingga melalui program ini, masyarakat RW 01 Desa Pasarean telah memiliki sense of belonging terhadap apa yang telah mereka kontribusikan untuk kepentingan pribadi maupun umum.

\section{DAFTAR PUSTAKA}

DeCesare, J.A. (2014). User Uploads and YouTube One Channels for Teaching, Learning, and Research. Library Technology Reports.

Faiqah F., M. Nadjib, A.A. Subhan. (2016). Youtube Sebagai Sarana Komunikasi Bagi Komunitas Makassarvidgram. Jurnal Komunikasi KAREBA, 5(2).

Jahi, A. (1988). Komunikasi Massa dan Pembangunan Pedesaa di Negara Dunia Ketiga Suatu Pengantar. Jakarta: PT. Gramedia.

Khatimah, H. (2018). Posisi dan Peran Media Dalam Kehidupan Masyarakat. Berugal Jurnal, 16(1), 119-139.

Krisyantono, R. (2010). Teknik Praktis Riset Komunikasi. Jakarta: Kencana Prenada Media Group.

Mangole KDB, M. Himpong M, E.R. Kalesaran. (2017). Pemanfaatan Youtube dalam Meningkatkan Pengetahuan Masyarakat di Desa Paslaten Kecamatan Remboken Minahasa. Acta Diurna Komunikasi, 6(4).

Mardikanto, T. (2010). Komunikasi Pembangunan Acuan Bagi Akademisi, Praktisi, dan Peminat Komunikasi Pembangunan. Surakarta: UNS Press.

Nasution, Z. (2009). Komuniaksi Pembangunan Pengetahuan Teori dan Penerapannya. Edisi Revisi. Jakarta: PT Rajagrafindo Persada.

Neumann, W. L. (2006). Social Research Methods. Qualitative and Quantitative Approach (Sixth Edition). Boston: Pearson.

Noegroho, A. (2010). Teknologi Komunikasi. Yogyakarta: Graha Ilmu.

Putri, D.M..(2013). Peran Media Online Dalam Pembangunan Provinsi Banten. Journal Communication Spectrum, 3(1).

Dharlinda, S. (2019). Pemanfaatan Media Komunikasi Dan Informasi Dalam Perwujudan Pembangunan Nasional. Jurnal Komunikasi Pembangunan,17(2).

Yunus, S. (2010). Jurnalistik Terapan. Bogor: Ghalia Indonesia.

Zarrella, D. (2010). The Social Media Marketing Book. Jakarta: PT Serambi Ilmu Semesta Anggota IKAPI. 